This is the Author Manuscript version of the article published in:

Journal of the American Chemical Society, 2016 October 12, 138 (40): 13143-13146

DOI 10.1021/jacs.6b07633

\title{
Reactivity of an Fe'v-Oxo Complex with Protons and Oxidants
}

\author{
Ethan A. Hill§, Andrew C. Weitz", Elizabeth Onderko $\ddagger$, Adrian Romero-Riveral, Yisong

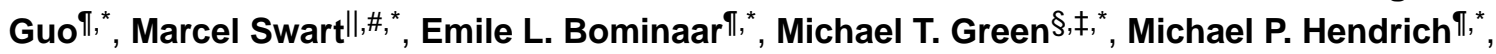 \\ David C. Lacy§, ${ }^{*} \dagger$, and A. S. Borovik $\$,{ }^{*}$ \\ $\S$ Department of Chemistry, University of California-Irvine, 1102 Natural Sciences II, Irvine, CA \\ 92697 \\ IDepartment of Chemistry, Carnegie Mellon University, Pittsburgh, PA 15213 \\ ‡Department of Chemistry, Pennsylvania State University, University Park, PA 16802 \\ "Institut de Química Computacional i Catàlisi \& Dept. Química, Universitat de Girona, 17003, \\ Spain
}

\#ICREA, Pg. Lluís Companys 23, 08010, Barcelona, Spain

\section{Abstract}

High valent $\mathrm{Fe}-\mathrm{OH}$ species are often invoked as key intermediates but have only been observed in Compound II of cytochrome P450s. To further address the properties of non-heme $\mathrm{Fe}^{\mathrm{IV}}-\mathrm{OH}$ complexes we demonstrate the reversible protonation of a synthetic $\mathrm{Fe}^{\mathrm{IV}}-$ oxo species containing a tris-urea tripodal ligand. The same protonated $\mathrm{Fe}^{\mathrm{IV}}$-oxo species can be prepared via oxidation, suggesting a putative $\mathrm{Fe}^{\mathrm{V}}$-oxo species was initially generated. Computational, Mössbauer, XAS, and NRVS studies indicate that protonation of the $\mathrm{Fe}^{\mathrm{IV}}$-oxo complex most likely occur on the tripodal ligand, which undergoes a structural change that results in the formation of a new intramolecular hydrogen bond with the oxido ligand that aids in stabilizing the protonated adduct. We suggest that similar species for protonated high valent $\mathrm{Fe}-$ oxo species may occur in the active sites of proteins. This finding further argues for caution when assigning unverified high valent $\mathrm{Fe}-$ $\mathrm{OH}$ species to mechanisms.

\section{Graphical Abstract}

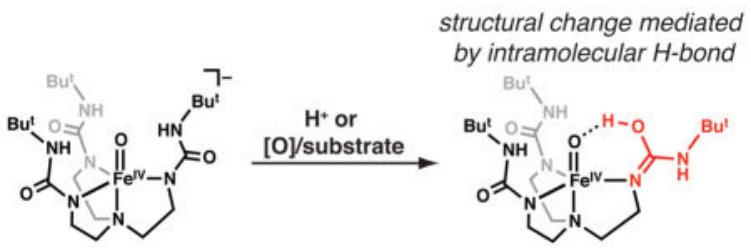

Corresponding Author: aborovik@uci.edu.

†resent Addresses

Department of Chemistry, University at Buffalo, 359 Natural Sciences Complex, Buffalo, NY 14260

Supporting Information

Experimental details for all reactions and physical measurements, and Figures S1-S12. This material is available free of charge via the Internet at http://pubs.acs.org. 
Metal-oxo/hydroxo species are important classes of intermediates that are involved in a variety of oxidative transformations in biology. ${ }^{1-3}$ The most well studied systems are produced from the activation of dioxygen or peroxide in heme enzymes. The paradigm systems are the cytochrome P450s (P450s), whose hydroxylase components have active sites that are composed of a single heme center and a hydrogen-bonding (H-bonding) network near the di-oxygen binding site. ${ }^{3-5} \mathrm{~A}$ common mechanistic proposal among P450s is that a high valent $\mathrm{Fe}$-oxo intermediate is formed from the binding and activation of dioxygen, which then serves as the kinetically competent species in the oxidation of substrates. ${ }^{5,6}$ The successful trapping of this transient intermediate in P450s (denoted Compound I) has provided sufficient spectroscopic and kinetic evidence to definitively assign it as a high valent $\mathrm{Fe}^{\mathrm{IV}}=\mathrm{O}$ (ligand radical) species, supporting the premise that high valent iron-oxo species are formed in monooxygenases. ${ }^{7}$ The mechanism proposed for the reactivity of Compound I involves the generation of an $\mathrm{Fe}^{\mathrm{IV}}-\mathrm{OH}$ species and a carbon radical from an initial C-H bond cleavage step (Scheme 1). ${ }^{3}$ The $\mathrm{Fe}^{\mathrm{IV}}-\mathrm{OH}$ species (Compound II) in P450s has taken on considerable importance with the findings of Green who suggested that its axial coordination to a thiolate ligand both lowers the reduction potential and increases the $\mathrm{Fe}^{\mathrm{IV}}$ $\mathrm{O} H \mathrm{p} K_{a}$ value to $\sim 12$ in Compound II. The attenuation of the reduction potential of Compound I and $\mathrm{p} K_{a}$ of Compound II prevents oxidation of neighboring tyrosine and tryptophan residues that would lead to protein destruction and facilitates $\mathrm{C}-\mathrm{H}$ bond cleavage (Scheme 1). ${ }^{8}$

The interplay between high valent $\mathrm{Fe}-\mathrm{Oxo}$ and $\mathrm{Fe}-\mathrm{OH}$ species also has importance in the function of heme-containing peroxidases. ${ }^{9,10}$ Recent experimental findings have sparked discussions on whether protonation occurs at the $\mathrm{Fe}^{\mathrm{IV}_{-}}$-oxo species or at a proximal site that then forms a H-bond to the oxido ligand. ${ }^{11,12}$ The importance of protonated $\mathrm{Fe}^{\mathrm{IV}}$-oxo species extends beyond heme proteins to non-heme systems that include the Rieske-type monooxygenases and synthetic systems, such as the one suggested by Fukusumi and Nam. ${ }^{13,14}$ Unlike non-heme $\mathrm{Fe}^{\mathrm{IV}}$-oxo species in which considerable progress has been made in understanding their properties, ${ }^{15-20}$ there is a dearth of experimental evidence for protonated non-heme, $\mathrm{Fe}^{\mathrm{IV}}$-oxo complexes. Nevertheless, it is assumed that protonation of synthetic $\mathrm{Fe}^{\mathrm{IV}}$-oxo complex occurs at the oxido ligand even though most $\mathrm{p} K_{\mathrm{a}}$ values for the $\mathrm{Fe}^{\mathrm{IV}-} \mathrm{OH}$ units are not known or thought to be less than $5 .{ }^{10,21-23}$ Furthermore, most synthetic systems lack intramolecular H-bonding networks that are vital in regulating the site of protonation in proteins with $\mathrm{Fe}^{\mathrm{IV}}$-oxo units. ${ }^{11,12}$

This report describes methods for the preparation of a protonated $\mathrm{Fe}^{\mathrm{IV}}$-oxo complex (1). We have previously generated a series of synthetic high valent metal-oxo species supported by the $\left[\mathrm{H}_{3} \text { buea }\right]^{3-}$ ligand (Scheme 2). ${ }^{20,24-28}$ Included in this series is the high-spin, mononuclear $\mathrm{Fe}^{\mathrm{IV}}$-oxo complex, $\left[\mathrm{Fe}^{\mathrm{IV}} \mathrm{H}_{3} \text { buea(O) }\right]^{-}(\mathbf{2})$, which has local $C_{3}$ symmetry that is enforced by the strong nitrogen donors of the deprotonated urea groups. ${ }^{20,29}$ In addition, the $\left[\mathrm{H}_{3} \text { buea }\right]^{3-}$ ligand promotes the formation of intramolecular $\mathrm{H}$-bonds and thus aids in regulating the secondary sphere around the iron center in a manner reminiscent of active sites in proteins. We have now used this approach to prepare $\mathbf{1}$, the protonated congener of $\mathbf{2}$, and characterize its physical properties. Moreover, we show that the same species is obtained via oxidation of 2 , implicating the formation of an $\mathrm{Fe}^{\mathrm{V}}$-oxo species. Our findings suggest 
that protonation of $\mathbf{1}$ does not occur at the oxido ligand, but rather at $\left[\mathrm{H}_{3} \text { buea }\right]^{3-}$, which undergoes a major structural change that is stabilized by a strong intramolecular $\mathrm{H}$-bond to the $\mathrm{Fe}^{\mathrm{IV}}$-oxo unit.

The starting point of our study was $\mathbf{2}$, whose conjugate acid has an experimentally estimated $\mathrm{pK}_{\mathrm{a}}$ value of $\sim 11 .{ }^{20,30}$ Based on the work on heme proteins described above, ${ }^{8}$ we reasoned that this value was sufficient to produce a protonated form that was stable enough to be detected. Consistent with this prediction, treatment of 2 with one equiv $\left[\mathrm{H}_{3} \mathrm{NPh}\right] \mathrm{BF}_{4}\left(\mathrm{pK}_{\mathrm{a}}=\right.$ 5.2 in THF, $\mathrm{rt})^{31}$ at $-80^{\circ} \mathrm{C}$ in THF produced a new species that we have assigned as the protonated analog 1 (Scheme 2). Spectrophotometric monitoring of the reaction showed replacement of the characteristic bands of 2 at $\lambda_{\max }=350,430,530$, and $810 \mathrm{~nm}$ with new peaks for 1 at $\lambda_{\max }=380$ and $540 \mathrm{~nm}$; this conversion exhibited isosbestic behavior upon incremental addition of the acid to a solution of $\mathbf{2}$ with isosbestic points observed at $\lambda=320$, 490 and $710 \mathrm{~nm}$ (Figure 1). The EPR signal from 2 vanished and a commensurate change was observed in the Mössbauer parameters from $\delta=0.04 \mathrm{~mm} / \mathrm{s}$ and $\Delta \mathrm{E}_{\mathrm{Q}}=0.50 \mathrm{~mm} / \mathrm{s}$ for 2 to $\delta=0.04 \mathrm{~mm} / \mathrm{s}$ and $\Delta \mathrm{E}_{\mathrm{Q}}=0.87 \mathrm{~mm} / \mathrm{s}$ for $\mathbf{1}$ (Figure 1). Variable field and temperature Mössbauer studies to be published later indicate an $\mathrm{S}=2$ spin ground state. We also explored this reaction with other acids at $-80^{\circ} \mathrm{C}$ in THF: complete formation of $\mathbf{1}$ was observed with 1.5 equiv of $\left[\mathrm{NH}\left(\mathrm{CH}_{2} \mathrm{CH}_{3}\right)_{3}\right] \mathrm{BF}_{4}\left(\mathrm{pK}_{\mathrm{a}}=12.5\right.$ in THF, $\left.\mathrm{rt}\right)$ but no reaction was found when 2 was treated with one equivalent of pyrrolidinium tetrafluoroborate $\left(\mathrm{pK}_{\mathrm{a}}=13.5\right.$ in THF, rt). ${ }^{31}$ These observations suggest an approximate bracketing of the $\mathrm{pK}_{\mathrm{a}}$ value for 1 between 11-13, which is consistent with our previous thermodynamic predictions for the $\mathrm{pK}_{\mathrm{a}}$ value for $\mathbf{1}$ in DMSO (see above).

The deprotonation of $\mathbf{1}$ was studied at $-80^{\circ} \mathrm{C}$ in THF using the non-nucleophilic base, diazabicycloundecene (DBU, $\mathrm{p} K_{\mathrm{a}} 16.8$ in THF, rt): ${ }^{31}$ both UV-vis and Mössbauer spectroscopies showed that $\mathbf{1}$ can be cleanly converted to $\mathbf{2}$ (Scheme 2, Figure S1) in a yield of $90 \%$. These results demonstrate the reversibility of the protonation/deprotonation process. Moreover, if our assignment of $\mathbf{1}$ is correct, a comproportionation reaction should occur between 1 and $\left[\mathrm{Fe}^{\mathrm{II}} \mathrm{H}_{3} \text { buea }(\mathrm{OH})\right]^{2-}$ (3, eq 1) to form $\left[\mathrm{Fe}^{\mathrm{III}} \mathrm{H}_{3} \text { buea }(\mathrm{OH})\right]^{-}$(4), two complexes that we have previously prepared and characterized. ${ }^{24,36}$ This premise was successfully affirmed by mixing equimolar amounts of $\mathbf{1}$ and $\mathbf{3}$ to afford $\mathbf{4}$ in a concentration that was twice that of the starting complexes. This reaction was followed using UV-vis and EPR spectroscopies, and the final product had identical spectra to those published for $\mathbf{4}$ (Figures S2 and S3). ${ }^{36}$ We also found that $\mathbf{1}$ can be reduced to $\mathbf{4}$ in nearly quantitative yield using $\left[\mathrm{CoCp}_{2}\right]$ as the reductant (eq 2, Figure S4). These results indicate that the molecular structure of $\mathbf{2}$ is not irreversibly changed upon protonation to form $\mathbf{1}$.

$$
\left[\begin{array}{l}
\|_{\mathrm{Fe}^{\mathrm{IV}}} \\
1 \\
1
\end{array}\right.
$$




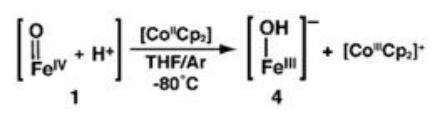

The vibrational properties of $\mathbf{1}$ were evaluated using nuclear resonance vibrational spectroscopy (NRVS). Using a sample that contained $80 \%$ of $1\left({ }^{57} \mathrm{Fe}-{ }^{16} \mathrm{O}\right)^{32}$ we obtained a NRVS spectrum with a peak at $800 \mathrm{~cm}^{-1}$ that is assigned to the $\mathrm{Fe}-\mathrm{O}$ vibration (Figure 2). This band shifts to $764 \mathrm{~cm}^{-1}$ in the $1\left({ }^{57} \mathrm{Fe}-{ }^{18} \mathrm{O}\right)$ isotopomer which is expected based on a harmonic $\mathrm{Fe}-\mathrm{O}$ oscillator model that predicts a difference of $36 \mathrm{~cm}^{-1}$. This vibrational feature does not originate from 2 because the sample had only $10 \%$ of 2 remaining. ${ }^{30}$ The NRVS spectrum of $2\left({ }^{57} \mathrm{Fe}-{ }^{16} \mathrm{O}\right)$ measured independently, and under identical conditions, showed a peak at $794 \mathrm{~cm}^{-1}$ that we had previously assigned to an $\mathrm{Fe}^{\mathrm{IV}}$-oxo vibration using FTIR spectroscopy. Furthermore, the lower energy features $\left(450-200 \mathrm{~cm}^{-1}\right)$ between $\mathbf{1}\left({ }^{57} \mathrm{Fe}-{ }^{16} \mathrm{O}\right)$ and $2\left({ }^{57} \mathrm{Fe}-{ }^{16} \mathrm{O}\right)$ that arise from $\mathrm{Fe}-\mathrm{N}$ vibrations are significantly different, indicative of a structural change upon protonation. We have also probed the structure of $\mathbf{1}$ using X-ray absorption spectroscopy. The XANES spectrum for $\mathbf{1}$ has an energy edge at $7122.9 \mathrm{eV}$ that is similar to the $7123.3 \mathrm{eV}$ value found for $\mathbf{2}$ (Figure S5); both edge energies are consistent with an $\mathrm{Fe}^{\mathrm{IV}}$ center. EXAFS analysis found that the $\mathrm{Fe}-\mathrm{O}_{\text {oxo }}$ bond lengths in $1(1.65 \AA)$ and $2(1.67 \AA)$ are the same within experimental error (Tables S1-S2, Figures S6-S7) with the distance in 2 matching that found by XRD on a crystalline sample. ${ }^{12} \mathrm{~A}$ Badger's rule analysis predicted that this $\mathrm{Fe}-\mathrm{O}$ bond distance measured for $\mathbf{1}$ would have an $v(\mathrm{Fe}-\mathrm{O})$ of $799 \mathrm{~cm}^{-1}$ which is in excellent agreement with our NRVS data. Note also that the two complexes have statistically significant differences in the remaining components of their primary coordination spheres. In particular, the EXAFS data for $\mathbf{1}$ were best fit to three $\mathrm{Fe}-\mathrm{N}$ bonds at a distance of $1.95 \AA$ while for $\mathbf{2}$ the fit gave four FeN bonds at a distance of 2.00. The details of these metrical differences are not yet known but it clear that structural changes occur upon conversion of $\mathbf{2}$ to $\mathbf{1}$.

We have used DFT methods to further understand the structural properties of $1 .{ }^{33}$ The DFT analysis suggests the added proton is located between the oxido group and one of the $\left[\mathrm{H}_{3} \text { buea }\right]^{3-}$ arms. Three low-energy optimized structures for 1 were found that differ by approximately $5 \mathrm{kcal} / \mathrm{mol}$ with 1 a predicted to be the lowest energy structure. The two lowest energy tautomers have the proton localized on $\left[\mathrm{H}_{3} \text { buea }\right]^{3-}$ (Figure 3 ). The structure of 1a has one urea group rotated such that one carbonyl group is positioned within the cavity with the proton on $\mathrm{O} 2$ (Figure 3). The rotated urea in 1 a adopts an imidic acid tautomer with a O2-C10 bond distance of $1.319 \AA$ and a relatively short N2-C10 bond length of $1.329 \AA$ (Table S3). ${ }^{34}$ The second tautomer $\mathbf{1 b}$ has the proton centered on one of the urea arms to form a quaternarized nitrogen center. The third structure $1 \mathbf{c}$ has the proton on the oxido ligand to form a hydroxo group. One urea arm in 1c is twisted, which is presumably to avoid steric clashing with the $\mathrm{O}-\mathrm{H}$ bond.

The Fe-O1 bond distances of 1.696 and $1.703 \AA$ in $\mathbf{1 a}$ and $\mathbf{1 b}$ are not significantly changed from the analogous bond distance of 1.680(1) $\AA$ in 2, which was determined by XRD and 
supported by XAS and DFT analyses. ${ }^{20,29,35}$ The long O1 $\cdots \mathrm{H} 1$ distances of $1.450 \AA$ in 1a and $1.549 \AA$ in $\mathbf{1 b}$ suggest that the apical ligand is better described as a H-bonded oxido than a hydroxido. However, the $\mathrm{O} 1 \cdots \mathrm{O} 2$ distance in $\mathbf{1 a}(2.495 \AA)$ and $\mathrm{O} 1 \cdots \mathrm{N} 3$ distance in $\mathbf{1 b}$ $(2.614 \AA$ ) are shorter than in other characterized monomeric $\mathrm{M}-\mathrm{OH}$ or $\mathrm{M}$-oxo structures with $\left[\mathrm{H}_{3} \text { buea }\right]^{3-}$, indicating that stronger $\mathrm{H}$-bonds are formed because of the increased acidity of these new H-bond donors. ${ }^{36}$ For $\mathbf{1 c}$, the Fe-O1 bond length is increased to 1.812 $\AA$ that reflects the formation of the hydroxido ligand. Moreover, DFT finds that in each tautomer an asymmetry exists within bond length being the equatorial plane that is caused by one $\mathrm{Fe}-\mathrm{N}_{\text {eq }}$ substantially larger (greater than $2 \AA$ ) than the others (Table S3); these bond length differences could explain the changes in the FeN vibrations observed between $\mathbf{1}$ and $\mathbf{2}$ by NRVS. Finally, DFT predicted that each tautomer has an $S=2$ spin state with computed Mössbauer parameters comparable to our experimental findings (Figure 3).

Based on the results from spectroscopy and computations, we argue that the oxido ligand in $\mathbf{1}$ is the less likely site of protonation. This claim is based on the similarities of the Fe-O vibrations for $\mathbf{1}$ and $\mathbf{2}$ as determined by NRVS measurements and the small changes in the $\mathrm{Fe}-\mathrm{O} / \mathrm{N}$ bond lengths between the two $\mathrm{Fe}^{\mathrm{IV}}$ complexes obtained from EXAFS analysis. We thus suggest that the protonation occurs on one of the urea arms of the $\left[\mathrm{H}_{3} \text { buea }\right]^{3-}$, as illustrated in the structures of $\mathbf{1 a}$ and $\mathbf{1 b}$. Based on relative free energy considerations, 1a and $\mathbf{1 b}$ are nearly equivalent and their Mössbauer parameters match well with values obtained from experiments. Tautomer $1 \mathrm{c}$ contains an $\mathrm{Fe}^{\mathrm{IV}}-\mathrm{OH}$ unit but with structural parameters that do not match those found by EXAFS. In addition, Badger's rule suggests an $\mathrm{Fe}-\mathrm{O}$ bond length of $1.81 \AA$ as computed for $1 \mathrm{c}$ would have a $v(\mathrm{Fe}-\mathrm{O})=573 \mathrm{~cm}^{-1}$, which does not agree with experiment (Figure 2). ${ }^{37}$

Complex 1 also can be obtained via the oxidation of $\mathbf{2}$. We previously reported that the $\mathrm{Fe}^{\mathrm{IV}}$-oxo complex 2 exhibits an irreversible oxidation at $0.34 \mathrm{~V}$ vs. $\left[\mathrm{FeCp}_{2}\right]^{+/ 0}$ in DMSO at room temperature that we now report shifts to $0.14 \mathrm{~V}$ in THF (Figure S8). To probe this oxidative event, the reaction between 2 and the radical amminium cation, $\mathrm{N}(p$-tol $) 3^{+\bullet}(0.4 \mathrm{~V}$ vs. $\left.\left[\mathrm{FeCp}_{2}\right]^{0 /+}\right)^{38}$ was monitored spectrophotometrically at $-80^{\circ} \mathrm{C}$ in THF. Rather than a new $\mathrm{Fe}^{\mathrm{V}}$ species that would be expected for single electron transfer, this reaction gave $\mathbf{1}$ as the major iron species in $60 \%$ yield. The formation of 1 was supported by spectrophotometric (inset, Figure 1) and Mössbauer experiments (Figure S9). The same results were also obtained when the reaction was performed at $-105^{\circ} \mathrm{C}$ in THF and $-120^{\circ} \mathrm{C}$ in 2-MeTHF. A mechanistic route that is consistent with these observations is the initial formation of an $\mathrm{Fe}^{\mathrm{V}}$-oxo intermediate (6) that, in the absence of external substrates, rapidly reacts with solvent to form 1 (Scheme 2). Because we have been unable to detect any oxidized products from THF, we examined this reaction with external substrates. The oxidized form of $\mathbf{2}$ did not react with external compounds such as 9,10-dihydroanthracene, but detectable products were observed with phenols. For instance, when 100 equiv of 2,4,6-tri-tert-butylphenol (7) were present in the oxidation reaction, the formation of $\mathbf{1}$ and the corresponding phenoxy radical (9) was observed, as evidenced by the appearance of its optical bands at $\lambda_{\max }=382$ and $402 \mathrm{~nm}$ (eq 3, Figures S10-S11). Moreover, 2,2' ,6, $6^{\prime}$-tetra-tert-butyl-4,4'-biphenol (10) was produced in a 20(5)\% yield when 2,6-di-tert-butylphenol (8) was used instead of 7, as determined by gas chromatography (GC) and GC-MS (Figures S12-S13). These results 
provide evidence that an $\mathrm{Fe}^{\mathrm{V}}$-oxo species could initially be formed during the oxidative conversion of $\mathbf{2}$ to $\mathbf{1}$.

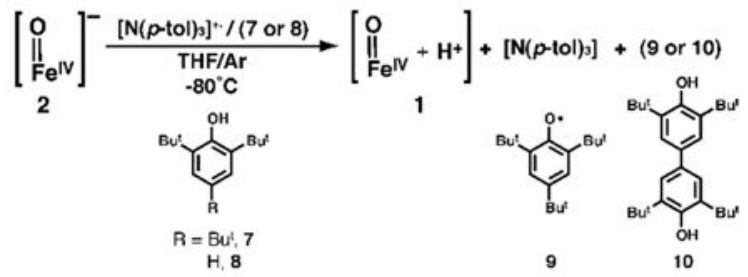

Protonated $\mathrm{Fe}^{\mathrm{IV}}$-oxo complexes are difficult to prepare, yet such species are proposed to readily form within protein active sites in which intramolecular $\mathrm{H}$-bonds within the secondary coordination sphere are prevalent. Using the synthetic ligand $\left[\mathrm{H}_{3} \mathrm{buea}\right]^{3-}$ that also promotes intramolecular H-bonds, we have demonstrated that the well-characterized $\mathrm{Fe}^{\mathrm{IV}}$ oxo complex $\mathbf{2}$ reacts with acids to produce a new species that is assigned to the protonated $\mathrm{Fe}^{\mathrm{IV}}$-oxo species $\mathbf{1}$. The properties and reactivity of $\mathbf{1}$ are all consistent with this assignment, including its reversion back to 2 with the addition of the base DBU, its reaction with the $\mathrm{Fe}^{\mathrm{II}}-\mathrm{OH}$ complex 3 to produce the $\mathrm{Fe}{ }^{\mathrm{III}}-\mathrm{OH}$ species $\mathbf{4}$, and its conversion to $\mathbf{4}$ by reduction with $\left[\mathrm{CoCp}_{2}\right]$. Insights into the structure of $\mathbf{1}$ came from spectroscopy and DFT calculations, which suggested that the likely site of protonation is the $\left[\mathrm{H}_{3} \text { buea }\right]^{3-}$ ligand. The results from NRVS spectroscopy indicated that the $\mathrm{Fe}^{\mathrm{IV}}$-oxo unit remains intact. In the lowest energy complexes from DFT, one tripodal arm is protonated, resulting in a new intramolecular H-bonding interaction with the $\mathrm{Fe}^{\mathrm{IV}}$-oxo unit. The computational studies implicate the $\mathrm{Fe}^{\mathrm{IV}}-\mathrm{O} \cdots \mathrm{H}-\mathrm{X}(\mathrm{X}=\mathrm{O}, \mathrm{N})$ intramolecular $\mathrm{H}$-bond as a key contributor to the stability of this structure.

Treatment of $\mathbf{2}$ with oxidant did not yield a detectable $\mathrm{Fe}^{\mathrm{V}}$ species that would be comparable to Compound I; instead, $\mathbf{1}$ was obtained in good yield. The detection of $\mathbf{1}$ provided the opportunity to examine its formation from routes similar to those used to produce Compound II in P450s. In the presence of phenolic substrates, the expected oxidation products were found, which indicated that a putative $\mathrm{Fe}^{\mathrm{V}}$-oxo species may have been produced. Taken together, our findings offer experimental and computational evidence that a synthetic protonated $\mathrm{Fe}^{\mathrm{IV}}$-oxo complex has been prepared via a route that is similar to that proposed in P450s. ${ }^{8}$

Our experimental results showed that $\mathbf{1}$ and $\mathbf{2}$ differ from one another by a single proton, but the combination of spectroscopy and theory suggests protonation of $\mathbf{2}$ most likely occurs on $\left[\mathrm{H}_{3} \text { buea }\right]^{3-}$ rather than forming an $\mathrm{Fe}^{\mathrm{IV}}-\mathrm{OH}$ unit as might be expected. The structure of $\mathbf{1 a}$ illustrates how an $\mathrm{Fe}^{\mathrm{IV}}-\mathrm{O}$ unit may assist in protonating a nearby functional group through formation of an intramolecular H-bond. We argue these types of interactions are not limited to just our system and may occur within the active site of a protein or a synthetic complex, especially those with presumed high valent $\mathrm{Fe}-\mathrm{OH}$ units. ${ }^{11,12}$ For instance, mechanisms for non-heme iron enzymes and their synthetic models often invoke $\mathrm{Fe}^{\mathrm{IV}}-\mathrm{OH}$ and $\mathrm{Fe}^{\mathrm{V}}-\mathrm{OH}$ 
intermediates, ${ }^{14,39-41}$ but evidence for the protonation of an $\mathrm{Fe}^{\mathrm{IV}}$-oxo unit has only been observed in heme-containing proteins such as Compound II of P450s and the chloroperoxidases. ${ }^{8,42,43}$ Such reactivity has yet to be definitively observed in other metalloproteins that invoke high valent $\mathrm{Fe}-\mathrm{OH}$ species such as the Rieske non-heme oxygenases. ${ }^{1,39}$ Our results question whether these high valent $\mathrm{Fe}-\mathrm{OH}$ species are the only intermediates in mechanisms other than P450s, particularly when protonation at other sites within the complex (or an active site) cannot be ruled out.

\section{Supplementary Material}

Refer to Web version on PubMed Central for supplementary material.

\section{Acknowledgments}

We thank the National Institutes of Health USA (GM050781 to ASB, GM49970 to MPH, and GM101390 to MTG), the Ministerio de Economia y Competitividad (CTQ2014-59212-P \&\& 2015FIB00165), and the European Fund for Regional Development (UNGI10-4E-801) for financial support, and E. E. Alp, J. Zhao, and M. Hu from the APS in the Argonne National Laboratory for the support in collecting NRVS spectra. Portions of this research were carried out at the Stanford Synchrotron Radiation Lightsource supported by DOE, OBES and NIH; we thank M Latimer and E. Nelson for assistance.

\section{References}

1. Costas M, Mehn MP, Jensen MP, Que L. Chem Rev. 2004; 104:939-986. [PubMed: 14871146]

2. Que L, Tolman WB. Nature. 2008; 455:333-340. [PubMed: 18800132]

3. Mas-Ballesté R, Que L. Science. 2006; 312:1885-1886. [PubMed: 16809517]

4. Poulos TL. Chem Rev. 2014; 114:3919-3962. [PubMed: 24400737]

5. Krest CM, Onderko EL, Yosca TH, Calixto JC, Karp RF, Livada J, Rittle J, Green MT. J Biol Chem. 2013; 288:17074-17081. [PubMed: 23632017]

6. Denisov IG, Makris TM, Sligar SG, Schlichting I. Chem Rev. 2005; 105:2253-2277. [PubMed: 15941214]

7. Rittle J, Green MT. Science. 2010; 330:933-937. [PubMed: 21071661]

8. Yosca TH, Rittle J, Krest CM, Onderko EL, Silakov A, Calixto JC, Behan RK, Green MT. Science. 2013; 342:825-829. [PubMed: 24233717]

9. Gumiero A, Metcalfe CL, Pearson AR, Raven EL, Moody PCE. J Biol Chem. 2011; 286:12601268. [PubMed: 21062738]

10. Behan RK, Green MT. J Inorg Biochem. 2006; 100:448-459. [PubMed: 16500711]

11. Chreifi G, Baxter EL, Doukov T, Cohen AE, McPhillips SE, Song J, Meharenna YT, Soltis SM, Poulos TL. Proc Natl Acad Sci U S A. 2016; 113:1226-1231. [PubMed: 26787871]

12. Casadei CM, Gumiero A, Metcalfe CL, Murphy EJ, Basran J, Concilio MG, Teixeira SCM, Schrader TE, Fielding AJ, Ostermann A, Blakeley MP, Raven EL, Moody PCE. Science. 2014; 345:193-197. [PubMed: 25013070]

13. Wackett LP. Enzyme Microb Technol. 2002; 31:577-587.

14. Park J, Lee YM, Nam W, Fukuzumi S. J Am Chem Soc. 2013; 135:5052-5061. [PubMed: 23528016]

15. Hohenberger J, Ray K, Meyer K. Nat Commun. 2012; 3:1-13.

16. McDonald AR, Que L. Coord Chem Rev. 2013; 257:414-428.

17. Puri M, Que L. Acc Chem Res. 2015; 48:2443-2452. [PubMed: 26176555]

18. Wang D, Ray K, Collins MJ, Farquhar ER, Frisch JR, Gómez L, Jackson TA, Kerscher M, Waleska A, Comba P, Costas M, Que L. Chem Sci. 2013; 4:282-291. [PubMed: 23227304]

19. Nam W, Lee YM, Fukuzumi S. Acc Chem Res. 2014; 47:1146-1154. [PubMed: 24524675] 
20. Lacy DC, Gupta R, Stone KL, Greaves J, Ziller JW, Hendrich MP, Borovik AS. J Am Chem Soc. 2010; 132:12188-12190. [PubMed: 20704272]

21. Yosca TH, Behan RK, Krest CM, Onderko EL, Langston MC, Green MT. J Am Chem Soc. 2014; 136:9124-9131. [PubMed: 24875119]

22. Jensen MP, Costas M, Ho RYN, Kaizer J, Mairata i Payeras A, Münck E, Que L, Rohde J-U, Stubna A. J Am Chem Soc. 2005; 127:10512-10525. [PubMed: 16045338]

23. Stoian SA, Xue G, Bominaar EL, Que L, Münck E. J Am Chem Soc. 2014; 136:1545-1558. [PubMed: 24380398]

24. MacBeth CE, Golombek AP Jr, VGY, Yang C, Kuczera K, Hendrich MP, Borovik AS. Science. 2000; 289:938-941. [PubMed: 10937994]

25. Borovik AS. Acc Chem Res. 2005; 38:54-61. [PubMed: 15654737]

26. Gupta R, Taguchi T, Lassalle-Kaiser B, Bominaar EL, Yano J, Hendrich MP, Borovik AS. Proc Natl Acad Sci U S A. 2015; 112:5319-5324. [PubMed: 25852147]

27. Cook SA, Borovik AS. Acc Chem Res. 2015; 48:2407-2414. [PubMed: 26181849]

28. Shook RL, Borovik AS. Inorg Chem. 2010; 49:3646-3660. [PubMed: 20380466]

29. Gupta R, Lacy DC, Bominaar EL, Borovik AS, Hendrich MP. J Am Chem Soc. 2012; 134:97759784. [PubMed: 22574962]

30. Usharani D, Lacy DC, Borovik AS, Shaik S. J Am Chem Soc. 2013; 135:17090-17104. [PubMed: 24124906]

31. Kaljurand I, Kütt A, Sooväli L, Rodima T, Mäemets V, Leito I, Koppel IA. J Org Chem. 2005; 70:1019-1028. [PubMed: 15675863]

32. Percentages were determined using Mössbauer spectroscopy. The samples used in these studies had less than a $10 \%$ impurity of 2.

33. Swart M, Solà M, Bickelhaupt FM. J Chem Phys. 2009; 131:094103. [PubMed: 19739845]

34. Fairlie DP, Taube H. Inorg Chem. 1985; 24:3199-3206.

35. Swart M. Chem Commun. 2013; 49:6650.

36. MacBeth CE, Gupta R, Mitchell-Koch KR, Young VG, Lushington GH, Thompson WH, Hendrich MP, Borovik AS. J Am Chem Soc. 2004; 126:2556-2567. [PubMed: 14982465]

37. Green MT. J Am Chem Soc. 2006; 128:1902-1906. [PubMed: 16464091]

38. Connelly NG, Geiger WE. Chem Rev. 1996; 96:877-910. [PubMed: 11848774]

39. Prat I, Mathieson JS, Güell M, Ribas X, Luis JM, Cronin L, Costas M. Nat Chem. 2011; 3:788793. [PubMed: 21941251]

40. Tiago de Oliveira F, Chanda A, Banerjee D, Shan X, Mondal S, Que L, Bominaar EL, Münck E, Collins TJ. Science. 2007; 315:835-838. [PubMed: 17185561]

41. Prat I, Company A, Postils V, Ribas X, Que L, Luis JM, Costas M. Chemistry. 2013; 19:67246738. [PubMed: 23536410]

42. Green MT, Dawson JH, Gray HB. Science. 2004; 304:1653-1656. [PubMed: 15192224]

43. Stone KL, Behan RK, Green MT. Proc Natl Acad Sci U S A. 2006; 103:12307-12310. [PubMed: 16895990] 

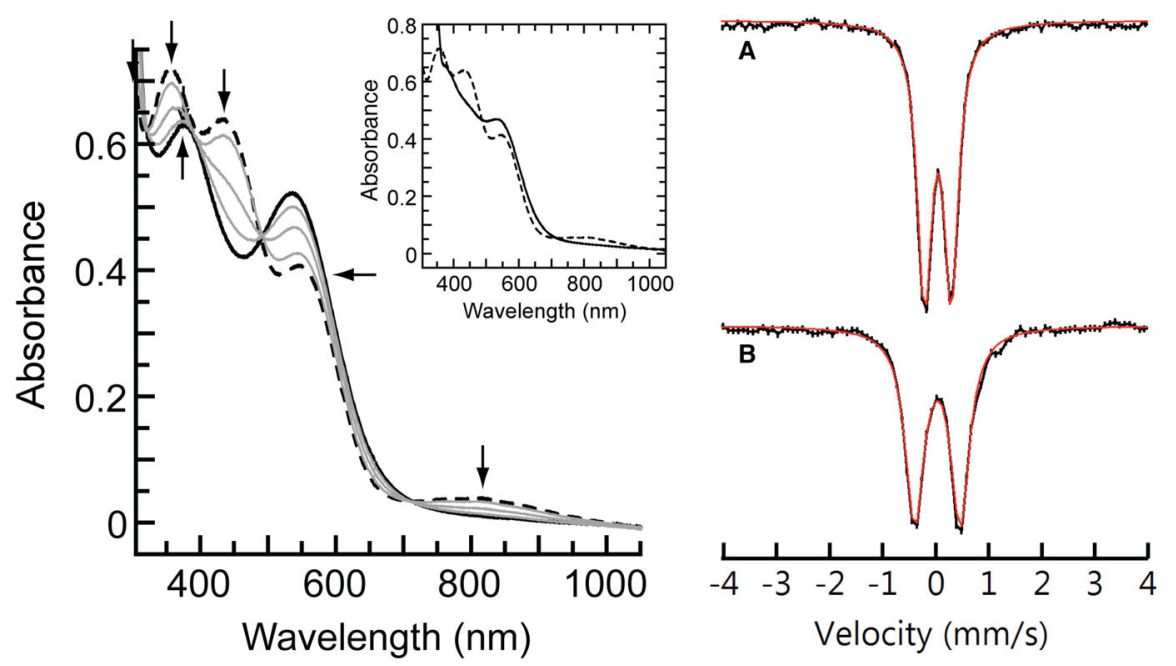

Figure 1.

Electronic absorbance spectra (left) for the protonation of $\mathbf{2}$ (dash) to $\mathbf{1}$ (solid) via sequential addition of $0.25,0.50,0.75$, and 1.0 equiv of $\left[\mathrm{H}_{3} \mathrm{NPh}\right]^{+}$at $-80^{\circ} \mathrm{C}$ in THF. Inset: Oxidation of 2 to 1 with $\mathrm{N}(p \text {-tol })_{3}{ }^{+\bullet}$ at $-80^{\circ} \mathrm{C}$ in THF. Mössbauer spectra (right) of $\mathbf{2}$ (A) and $\mathbf{1}$ (B) recorded at $4 \mathrm{~K}$ in THF. Red lines are the least-square fits of the experimental data with linewidths: (A) $0.32 \mathrm{~mm} / \mathrm{s}$, (B) $0.37 \mathrm{~mm} / \mathrm{s}$. 


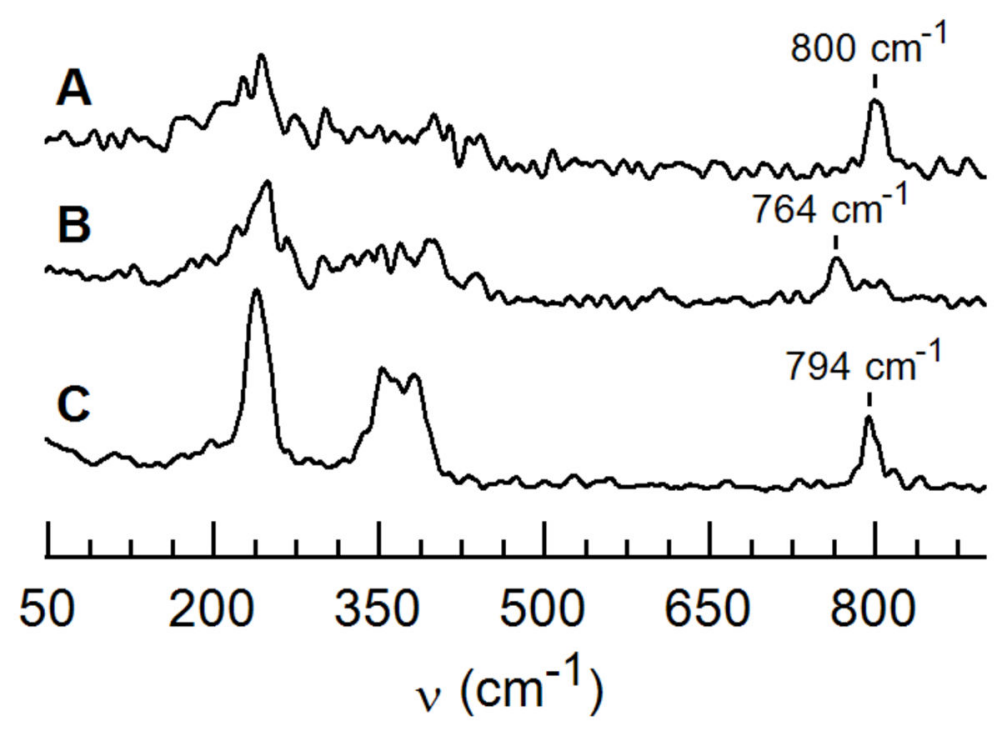

Figure 2.

NRVS spectra for $\mathbf{1}\left({ }^{57} \mathrm{Fe}-{ }^{16} \mathrm{O}\right)(\mathbf{A}), \mathbf{1}\left({ }^{57} \mathrm{Fe}_{-}{ }^{18} \mathrm{O}\right)(\mathbf{B})$, and $2\left({ }^{57} \mathrm{Fe}-{ }^{16} \mathrm{O}\right)(\mathbf{C})$. Samples were $\sim 10 \mathrm{mM}$ in THF. 

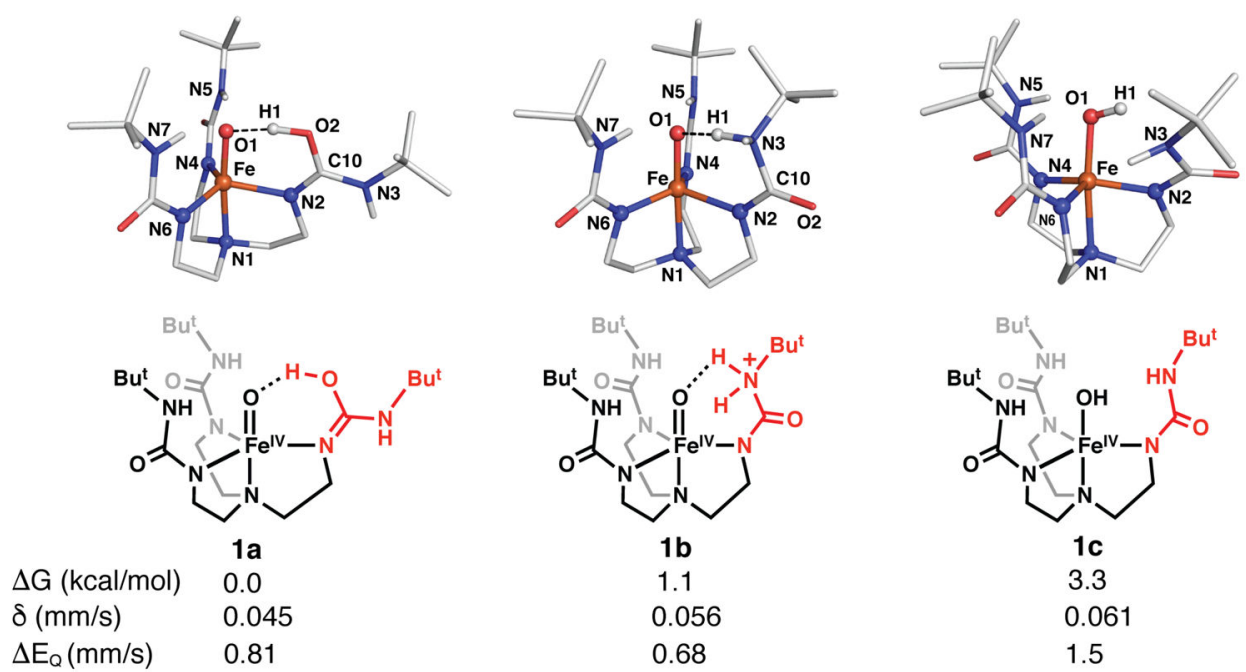

Figure 3.

Geometry optimizations, relative free energies at RT, and computed Mössbauer parameters for 1a-1c determined from DFT. The red segments represent key structural aspects of $\left[\mathrm{H}_{3} \text { buea }\right]^{3-}$. 
RC-H

\section{RC -}

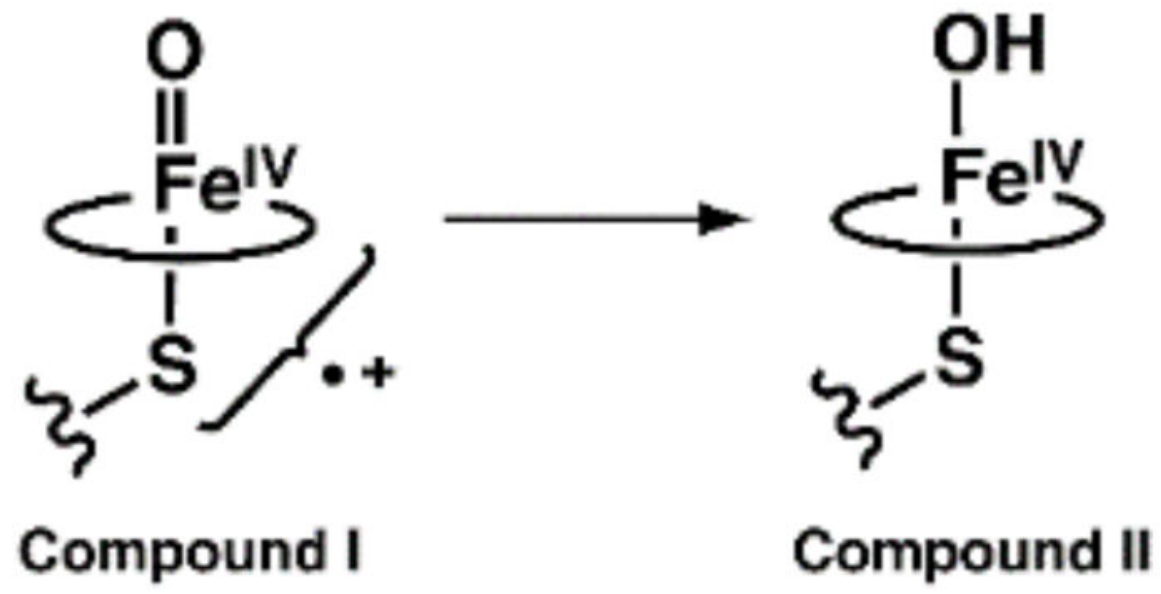

Scheme 1.

Proposed route for $\mathrm{C}-\mathrm{H}$ bond cleavage by cytochrome $\mathrm{P} 450$. Circles represent protoporphyrin I. 


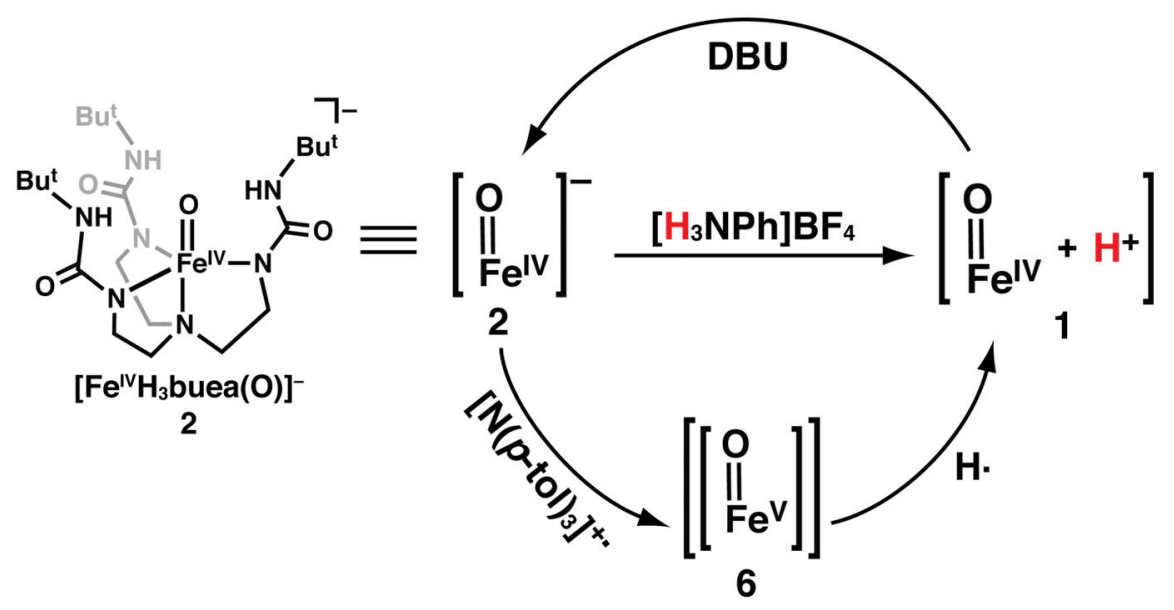

Scheme 2.

Reactivity of 2 at $-80^{\circ} \mathrm{C}$ in THF. 